NY SCHOOL DIGITAL REPOSITORY

$1-1-2008$

\title{
American Sovereigns: The People and Americas Constitutional Tradition Before the Civil War
}

Christian G. Fritz

University of New Mexico - School of Law, fritz@law.unm.edu

Follow this and additional works at: https://digitalrepository.unm.edu/law_facbookdisplay

Part of the Law Commons

\section{Recommended Citation}

Fritz, Christian G.. "American Sovereigns: The People and Americas Constitutional Tradition Before the Civil War." (2008): 427 pages. https://digitalrepository.unm.edu/law_facbookdisplay/19

This Book is brought to you for free and open access by the School of Law at UNM Digital Repository. It has been accepted for inclusion in Faculty Book Display Case by an authorized administrator of UNM Digital Repository. For more information, please contact amywinter@unm.edu, Isloane@salud.unm.edu,sarahrk@unm.edu. 
Cambridge University Press

978-0-521-88188-3 - American Sovereigns: The People and America's Constitutional Tradition Before the Civil War

Christian G. Fritz

Excerpt

More information

\section{Prologue}

This book is a history of an idea and of a people who tried to live by that idea. The idea is what we know today as American constitutionalism. ${ }^{1}$ It defines "the people" as the sovereign whose written constitution grants and guides the legitimate exercise of government authority. The fact that the people, instead of a king, ruled in America justified the Revolution as well as the governments established in its wake. When New Yorkers pulled down the statue of George III in Battery Park shortly after Congress declared independence, they did more than reject British authority over America. Their action symbolized the replacement of the person of the king as the sovereign by the collective body of the people as America's new sovereign.

The Revolution stimulated the interest of Americans in their new governments and the people's relationship to them. Revolutionary leaders stressed the important role the people played in securing America's independence. In framing America's first constitutions, patriots celebrated the people's sovereignty. These ideals smoldered even after the Revolution ended and this heated revolutionary rhetoric soon permeated all regions and ranks of society. Government was no longer something that happened to people. In America it now became something that the people - by their consent and volition - brought into being. The people gave their consent through their conduct and their active participation reinforced the message that the people were America's new sovereign. ${ }^{2}$

Constitutional arguments about the people's sovereignty soon became familiar to ordinary Americans who knew these arguments because they participated in them zealously. Americans argued fiercely about the nature and the extent of their power as part of the collective sovereign, and seven decades later they were no closer to agreement over what the people's sovereignty meant than they were during the Revolution. Yet their disagreements produced a complex constitutional tradition that we have generally overlooked. 


\section{Cambridge University Press}

978-0-521-88188-3 - American Sovereigns: The People and America's Constitutional Tradition Before the Civil War

Christian G. Fritz

Excerpt

More information

\section{Prologue}

How the people could collectively act as the sovereign has remained a persistent puzzle. This elemental question shaped constitutional debates from the time of Independence. Yet, because the constitutional principle of the people's sovereignty has been largely overlooked, much of the reasoning driving these debates has been obscured. ${ }^{3}$

The emergence of a dominant understanding about American constitutionalism was not the result of a single defining event such as the federal constitutional convention. Rather, it developed incrementally through successive political controversies at the state and national levels that are the subject of this book. It is hoped that a rekindled interest in the significance of these past struggles may illuminate the continuing growth and development of American constitutionalism.

The constitutionalism of America during the decades following Independence differed from today's constitutionalism. The crux of this difference lies in the novel question that American constitutionalism faced in the wake of independence: how could a collectivity - a people rather than a monarch rule as the sovereign over a region larger and more diverse than Europe? Moreover, how could that sovereign speak clearly with one voice on matters of state as well as national concern?

After the Revolution, few disputed that the people would rule as the sovereign speaking through written constitutions. But in putting this idea into practice, Americans parted company with one another. Their division did not end with the drafting and ratification of the federal Constitution. How the people should govern through constitutions surfaced in many hardfought political controversies thereafter. Yet the promise of constitutionalism remained bright even as the nation grew and drifted toward disunion and civil war.

Today it is difficult to imagine a time when it was not widely assumed that the constitutional vision of the federal Framers epitomized American thinking on government. Invariably, we trace the roots of our constitutionalism back to the unique federal convention that met in Philadelphia during the summer of 1787 . This singular focus on the federal Constitution assumes that little of constitutional importance happened at the hundred other state constitutional proceedings in America before the Civil War. If scholars give them any historical treatment, these other proceedings appear as variations on the constitutional themes of the federal convention. ${ }^{4}$

Those state proceedings, like the political controversies described in this book, raised questions about implementing the sovereignty of the people. They reveal very different views about the people as the sovereign from those reflected in the federal Constitution and dispel the notion that our prevailing 


\section{Cambridge University Press}

978-0-521-88188-3 - American Sovereigns: The People and America's Constitutional Tradition Before the Civil War

Christian G. Fritz

Excerpt

More information

\section{Prologue}

constitutional view is an unbroken chain stretching back to $1787 . .^{5}$ Indeed, many of our contemporary constitutional perspectives that echo those of the federal Framers were not inevitable; they did not become America's constitutional norms in 1787 , or in 1800 , or in 1840 . Those norms emerged only after a protracted struggle. The views of the federal Framers predominate today not as a natural inheritance but as the result of conscious choices made over the years among competing visions.

The sovereign people's ability to change constitutions was frequently discussed, often exercised, and invariably disputed after the creation of the federal Constitution. Contrary to much scholarship, Americans vigorously debated whether "the people" could express their sovereign will in changing constitutions only by using government-sanctioned procedures. ${ }^{6}$ Whether Americans found it necessary to use such procedures reflected contrasting views of the relationship of the people to their government. One view saw the people dependent on government and procedure while another view did not. Both views shared the general consensus of American revolutionaries that a majority of the people were the sovereign. Disagreement arose over how much power remained with "the people" and how much power "the people" relinquished to their elected officials.

It seems puzzling today that Americans once considered their sovereign to be the people acting collectively. Modern scholars suggest that sovereignty of the people was a rhetorical flourish lacking practical application as a constitutional principle. As a crucial "fiction," the people's sovereignty had enormous political influence. ${ }^{7}$ But modern accounts of America's constitutional history neglect the constitutional authority once imputed to such a collective sovereign and as such they fail to appreciate the earlier existence of a widely held belief in collective sovereignty that lost sway only after the Civil War.

The lost view of sovereignty assumed that a majority of the people created and therefore could revise constitutions at will, and that a given majority of one generation could not limit a later generation. America's first constitutions, being an expression of the people's sovereignty, could not be turned against the majority of the people. Indeed, those constitutions frequently contained express provisions recognizing the broad scope of the people's authority. Such statements encouraged an expansive view of constitutional revision. The essence of the rule of law - that binding law exists above both the governors and the governed alike - was challenged by the idea that a sovereign people could not be bound even by a fundamental law of their own making. ${ }^{8}$

Under that expansive view, adhering to procedures specifying constitutional change provided one means of determining the will of the sovereign. 


\section{Cambridge University Press}

978-0-521-88188-3 - American Sovereigns: The People and America's Constitutional Tradition Before the Civil War

Christian G. Fritz

Excerpt

More information

Nonetheless, constitutional text requiring special majorities could not prevail over the clear will of a majority to dispense with such requirements if that majority so desired. The key to legitimacy was whether constitutional change expressed the will of the collective sovereign, not adherence to specific procedures. While Americans frequently followed such procedures, for many those steps were simply useful, not indispensable. They were not the only legitimate tools available for a sovereign to articulate its will. $^{9}$

For other Americans, once the people created a government, it became the conduit and the enforcer of that sovereign's will. If the people placed procedures in their constitution, they effectively exercised their unlimited power to limit themselves by those procedures. The people could not ignore the procedures they imposed upon themselves. This view of constitutionalism asserted that the people's unbounded power included the ability to bind themselves by their constitution and to bind future generations.

This constrained view of constitutional change made procedure the test of legitimacy. It assigned the people a passive role in making and altering constitutions, one that emphasized deference to elected leaders. Even advocates of a constrained view, however, dispensed with restrictive formal requirements when it seemed necessary. Their adherence to procedure was not absolute. They believed that government could enforce constitutional requirements for changing the constitution, but conceded that a majority of the people might deviate from specified procedures with the sanction of the government. Only when the government insisted on the formalities for change were the people required to follow them. Under this view government could repudiate change that defied stated procedures, but it could also validate constitutional revision under the people's authority that bypassed procedures.

Despite their consensus about the existence of the collective sovereign, Americans vigorously disagreed and, as the Civil War approached, forcibly disputed whether constitutional change was possible only through a process guaranteed by government. Both the expansive and the constrained views acknowledged the sovereign authority of the people. Each side accused the other of betraying the Revolution. Thus, the development that gave Americans their greatest pride in their new, postrevolutionary governments - written constitutions authorized by the people - also represented the most contentious aspect of their experiment with republicanism. Many leaders of the revolutionary movement became increasingly sensitive to the latent potential of sweeping changes made in the name of the people. After observing the operation of the legislatures under the first state constitutions, they became 


\section{Cambridge University Press}

978-0-521-88188-3 - American Sovereigns: The People and America's Constitutional Tradition Before the Civil War

Christian G. Fritz

Excerpt

More information

\section{Prologue}

alarmed at the increasing influence of those who traditionally did not exercise positions of political leadership.

While American revolutionaries spoke with one voice in affirming the people's sovereignty, they did not speak with one voice about who counted as "the people." Initially, "the people" excluded women, those lacking property, Native Americans, and African Americans - even as the Revolution stimulated challenges to such exclusion. ${ }^{10}$ Only in the course of the nineteenth and twentieth centuries would the definition of "the people" expand and become increasingly inclusive. As Americans wrestled with defining "the people," their answers to the question of who composed the collective sovereign varied over time and by place. Broader or narrower definitions of "the people" reflected different attitudes toward political participation, who should vote, and the perceived dangers of legislative majorities.

Even if a majority of "the people" - however defined - and not simply a faction took a given position, the issue became how that collective sovereign could express its will simultaneously and definitively. In a variety of disputes after Independence, Americans struggled to answer that question. The issue of the people's sovereignty arose in disagreements over such matters as taxes, court procedures, government reform, decisions to wage war, and the scope of dissent. The way the collectivity of the people acted as the sovereign was answered piecemeal. In those debates Americans tended to talk past one another. Some focused on the need for constitutional procedures before a collective sovereign could change the constitution. They also expected the existing government to be involved in the revision process. Others rejected such restraints on the people's sovereign authority. They believed that procedural restraints would make the servants, the elected officials, more powerful than the master, the sovereign people. In this view, a majority of the people possessed the inherent right to make constitutional changes, even independent of government.

American thinking about written constitutions can be traced through a series of events between the revolutionary era and the Civil War, beginning with the ways Americans employed the authority of the collective sovereign first to abolish and then to create governments during the Revolution. Part One of this book - "The People's Sovereignty in the States," (Chapters 2-4) describes the origins and early application of the idea that the people were the sovereigns who created constitutional government in the states and on the frontier. This part concludes with Shays's "rebellion," a postrevolutionary struggle in Massachusetts over implementing the people’s sovereignty.

The federal Constitution incorporated a particular version of rule by a sovereign people. Even so, as illustrated in Part Two - “The Sovereign 


\section{Cambridge University Press}

978-0-521-88188-3 - American Sovereigns: The People and America's Constitutional Tradition Before the Civil War

Christian G. Fritz

Excerpt

More information

Behind the Federal Constitution" (Chapters 5-7) - the adoption of the federal Constitution reflected no consensus on how the people could express their sovereignty. Establishing constitutional government at the national level illustrates this lack of consensus, as do the events of another "rebellion," the Whiskey Rebellion in Pennsylvania, as well as the Virginia and Kentucky Resolutions, the Hartford Convention, and the Nullification crisis.

The final section of the book, Part Three - "The Struggle over a Constitutional Middle Ground" (Chapter 8) - explores the American puzzle of a collective sovereign, a sovereign that simultaneously rules and is ruled. Chief Justice John Jay commented on that novelty in 1793 when he said the American people were "sovereigns without subjects" who "have none to govern but themselves." 11 A definitive answer to the riddle of a collective sovereign still eluded Americans seventy years after Independence in the so-called Dorr "rebellion" in Rhode Island. The Epilogue of this book (Chapter 9) is not a summary of the work but rather seeks to identify broader themes in American constitutionalism before the Civil War, drawing from a consideration of the preceding chapters as a whole. It also suggests other avenues for further inquiry based on the findings of this study.

The events discussed in this book entailed constitutional questions as well as questions of constitutionalism. The political controversy over the Virginia and Kentucky Resolutions, for example, protested the constitutionality of laws passed by the Federalist Party that were aimed at their Republican opponents. Likewise, disputes between the North and South during the Nullification crisis involved sectional efforts to adjust the distribution of state and national power under the federal Constitution. These political and constitutional controversies also posed questions of constitutionalism - how to identify the collective sovereign, what powers the sovereign possessed, and how one recognized when that sovereign acted. Unlike constitutional questions, questions of constitutionalism could not be answered by reference to given constitutional text or even judicial opinions. Rather, they were openended questions drawing upon competing views Americans developed after Independence about the sovereignty of the people and the ongoing role of the people to monitor the constitutional order that rested on their sovereign authority.

This book tells a complicated story. Not everything "the people" did was an expression of their sovereign authority. The revolutionary idea of a collective sovereign suggested that the people might act in at least three capacities under a written constitution. First, the people could act as the sovereign, when, for example, they breathed life into a constitution. This was the most basic understanding of the role of the people. It encompassed not only the 


\section{Cambridge University Press}

978-0-521-88188-3 - American Sovereigns: The People and America's Constitutional Tradition Before the Civil War

Christian G. Fritz

Excerpt

More information

\section{Prologue}

creation of a constitution but also its amendment, or revision, or even its "abolition." In their capacity as the collective sovereign, the people were not limited in revising or abolishing their constitution through constitutional revision procedures. As the sovereign they were ultimately free to use and invoke their authority as they saw fit.

In creating the new American constitutions, the people built a structure for a republican form of government. Because government was subordinate to the people and representatives were the people's agents, the people might act in a second capacity as "the ruler" to monitor the constitutional order established under their authority as the collective sovereign. One way they did this - but not the only way - was through the voting process in which they elected legislative representatives and state executives. These elections were not acts by a "sovereign." They were simply choices by "the ruler" to designate agents to run the government, much the way a sovereign king might select ministers. As electors, if the people believed their agents or the government acted outside the constitutional framework or undermined the constitutional order, or simply took steps that were imprudent or unwise policy, they could refuse to continue those agents of government in office.

In contrast to the people's function as "the ruler," American constitutions also contemplated a role for the people as "the ruled." In this third capacity the people - as individuals or in groups - had rights granted by the constitution to express their views on the policy and conduct of the government or even on the constitutionality of government actions. In making these expressions, the people did not act with the authority of the collective sovereign. When the people petitioned government or assembled to express their views they were simply engaged in a political role anticipated for the people in governments framed by the constitutional authority of the collective sovereign. Indeed, the commitment to a collective sovereign as a central tenet of the Revolution stimulated ever-broader claims and more inclusive definitions of who "the people" were and what rights they had in political participation.

Differentiating among the people acting as the collective sovereign, as "the ruler" acting within the constitutional framework, or as "the ruled" engaged in political participation was not easy because the distinctions were subtle. ${ }^{12}$ Thus, it should not be surprising that Americans before the Civil War struggled to come to terms with the constitutionalism launched by the Declaration of Independence. Ideas of a collective sovereign were expounded and acted upon in the course of winning the Revolution. However, once the Revolution and the new American governments were justified by the authority of the people as the collective sovereign, the idea of the people's authority was not 
Cambridge University Press

978-0-521-88188-3 - American Sovereigns: The People and America's Constitutional Tradition Before the Civil War

Christian G. Fritz

Excerpt

More information

Prologue

abandoned, even though Americans continued to struggle with what that idea meant.

The different roles the people could play under the concept of a collective sovereign were not a figment of a revolutionary imagination. It was part of a riddle inherent in the idea that a people actually could be the sovereign. That riddle remained unanswered even as America drew closer to civil war. The different dimensions of the people's authority had a natural tendency to blend into one another. This tendency was exacerbated during the heat of many political controversies. At such times, the ambiguity of the idea of the collective sovereign served to unify as well as divide Americans not simply on the expediency of policy, but also on the very basis of their Union.

The diverse events considered in this work share a unified theme. As political disputes the events raise unrelated constitutional questions. Considered in light of their implications for American constitutionalism, however, the events illustrate the dynamic, ongoing enterprise of giving life to the idea of a collective sovereign. This idea presented an important question for Americans then, and it remains just as vitally important today: what does it mean that in America "the people" rule? 
Cambridge University Press

978-0-521-88188-3 - American Sovereigns: The People and America's Constitutional Tradition Before the Civil War

Christian G. Fritz

Excerpt

More information

\section{PART ONE}

\section{The People's Sovereignty in the States}

Independence created the need to frame new governments that reflected the legitimizing authority of the people. Steeped in English legal traditions, Americans engaged in constitution-making without completely appreciating the implications of that task. Revolutionaries agreed that the people were the new sovereigns of America who displaced the king. What that implied for traditional models of government and the relationship of the people to their new governments, however, only became clear to Americans at different times and in different ways. All of America's first written constitutions embraced the people's sovereignty and many of them expressed the inherent right of the people to scrutinize their governors and to effect constitutional change. Those constitutions reflected how deeply and widely patriots celebrated "the people" as the new sovereigns of America.

To a remarkable extent, the principles identified by America's constitutionmakers resonated with Americans at the grassroots level. Far from centers of government, ideas that led to Independence and fueled the Revolution took hold among ordinary people. Reacting to local concerns while embracing the revolutionary cause, Americans made arguments drawn from the authority of the people's sovereignty, much like their state and national leaders.

The prevalence of ideas about a collective sovereign that invited challenges to the decision making of the newly created American governments inevitably triggered a reaction. Political grievances raised questions of constitutionalism when those who expressed disagreement with policies of state governments were denied the right to do so. Matters escalated as frustrated opponents of those policies increasingly took matters in their own hands. They asserted the right of the body of "the people" to check acts of 
Cambridge University Press

978-0-521-88188-3 - American Sovereigns: The People and America's Constitutional Tradition Before the Civil War

Christian G. Fritz

Excerpt

More information

10

The People's Sovereignty

government that were believed to undermine the public welfare. In the late 1780s, Massachusetts witnessed a clash between Americans that advanced distinct views of what governments founded on the sovereign people meant in practice. 